\title{
Views of Classroom Education Department Teacher Candidates about Ideal Physical Sciences Teaching
}

\author{
Ahmet Turan Orhan \\ Faculty of Education, Sivas Cumhuriyet University, Turkey
}

Copyright $\subset 2019$ by authors, all rights reserved. Authors agree that this article remains permanently open access under the terms of the Creative Commons Attribution License 4.0 International License

\begin{abstract}
The goal of this research is to present the ideas and views of teacher candidates in the department of classroom education about an ideal physical sciences class. Qualitative research model was used in the process of forming the study, during which interviews with classroom teacher candidates were held; the obtained data is presented in the study through descriptive analysis. Study group of the research involves a total of 40 teacher candidates who studied in Sivas Cumhuriyet University, Faculty of education, Department of Basic Education, Classroom Education; students involved in the study were at 4th grade during 2018-2019 fall semester and had taken Science and Technology teaching I and Science and Technology teaching II lessons. Teacher candidate interview form, which was created by the researcher, was used in the study as the data collection tool. At the end of research, views of teacher candidates were divided into three basic categories; these categories are: Positive teacher features for an ideal physical sciences class, Negative teacher features in physical sciences class and Issues that should be researched and focused by a teacher for an ideal physical sciences class. The study presents prospective detailed viewpoints of teacher candidates about physical sciences teaching after they had received science teaching lessons.
\end{abstract}

Keywords Science Education, Teacher Candidates, Classroom Education

\section{Introduction}

Firstly, it is necessary to associate the general developments in information and technology with physical sciences and science education. Besides having a significant role in the development and progress of a nation, physical sciences are highly important for individuals in interpreting the world and life. Developments in physical sciences make important changes in human life and they serve humanity by generally easing the course of life.

In Turkey, 2013 Physical Sciences Class Education
Program had undergone some significant changes and was replaced by 2017 Physical Sciences Class Education Program which started to be applied in 2017-2018 Education Year (1st and 5th grades) [1]. The last version of this Education Program (with a few changes in 2017 program) was shaped and started to be applied as 2018 Physical Sciences Class Education Program [2]. According to this program, classroom teachers working with 3rd and 4th grades of Primary school students teach physical sciences for 3 hours per week.

Analyzing the characteristics of both students and teachers is a part of science education besides the application of Physical Sciences Class Education Program. Educators should know the learning processes of children, who are at the center of learning process; on the other hand, basic goals of education and features of an efficient teacher should be precisely defined [3]. The ultimate goal of physical sciences education, which involves various significant questions such as "How do the primary school children learn sciences more easily, what are the efficient factors in the process of obtaining best learning, what should be prevented in order to obtain this learning, what are the effects of new teaching strategies?”, is to improve classroom practices [4]. Certainly, competences and features of teachers are highly significant in these classroom practices.

While competence is the state of having knowledge and ability sufficient for demonstrating a behavior, competence in the proficiency of teaching can be defined as acquiring knowledge and abilities that are required for the service of teaching [5]. A successful teacher proceeds actions on the way to reaching perfection, he/she slowly discovers his/her personal best style through critical questioning and sees teaching process as a life-long development process; all of his/her actions are based on these basic, significant principles [3].

Besides having general teaching abilities and features, science teachers should have knowledge, ability and attitudes that are specifically required by the field of physical sciences. Competence, attitudes and behaviors are highly significant elements for a successful science class. 
There are various researches in Turkey about teacher candidates and their roles in classroom education; many of these researches are analyzed in terms of their contributions to science education, related results are evaluated and suggestions are made [6-15].

Researches about the views of teacher candidates in Classroom education department about science lessons they had during university education are generally based on the studies about the attitudes towards science and self-sufficiency in terms of physical sciences. For instance, Özden, Kara and Tekin [12] made a research and analyzed the attitudes of teacher candidates in classroom teaching departments towards science teaching classes; at the end of the study process, they presented the contribution of science teaching classes to the attitudes towards science. Yener and Yilmaz [14] analyzed the relation between learning-teaching understandings and beliefs about self-sufficiency of teacher candidates in classroom education department. In another study, Yildiz Duban and Gökçakan [15] determined that there is a positive and meaningful relation between the beliefs of classroom department teacher candidates in terms of their self-sufficiency in science teaching and their attitudes towards science teaching.

When the researches about the issue in Turkey are analyzed, it can be said that there is almost no prospective study focusing on presenting the views of teacher candidates in classroom education department about teaching in physical sciences classes after they received science education lessons.

The goal of this research is to present the views of classroom education department teacher candidates about an ideal physical sciences lesson. The sub-problems that will be analyzed in this study are:

According to teacher candidates in classroom education department:

1. What are the positive features of a teacher for an ideal physical sciences lesson?

2. What are the negative features of a teacher in a physical sciences lesson?

3. Which issues should be carefully researched and analyzed by a teacher for an ideal physical sciences lesson?

\section{Materials and Methods}

Model, data collection tool, data collection process and analysis of the obtained data are explained in this section.

\subsection{Research Model}

Qualitative research model is used in this study; interviews with teacher candidates are carried out and obtained data are presented through descriptive analysis. This analysis method enables dividing semi-structured questions into some specific categories and supporting them with direct quotations [16].

\subsection{Study Group}

Study group of the research involves a total of 40 teacher candidates who studied in Sivas Cumhuriyet University, Faculty of education, Department of Basic Education, Classroom Education; students involved in the study were at 4th grade in 2018-2019 fall semester and had taken Science and Technology teaching I and Science and Technology teaching II classes.

\subsection{Data Collection Tool}

Teacher candidate interview form created by the researcher is used as the data collection tool. Semi-structured interview form, created in order to obtain the views of teacher candidates about science teaching practices in classrooms, involves 5 open-ended questions and tips about these questions. Teacher candidates had approximately 20 minutes to answer the questions in the form.

\subsection{Data Analysis}

For descriptive analysis, categories for semi-structured questions are created and obtained data are processed according to these categories. Descriptions presented in these categories are supported by the direct views taken from teacher candidates. Interviews held with teachers are noted down by the researcher and interview processes are audio-recorded. Records of interviews are then computerized. In order to be able to decode the voice records, interviews are lined up; for instance, "T1" stands for the first teacher candidate. The organized data set is analyzed by another researcher and goodness of fit percentage is found to be .90 . This value shows that the research is reliable and sufficient (min. goodness of fit value should be $80 \%$ ) [17].

\section{Findings}

Views of teacher candidate in Classroom education department are divided into these three basic categories:

1. Positive features of a teacher for an ideal physical sciences lesson.

2. Negative features of a teacher for a physical sciences lesson.

3. Issues that should be carefully researched and focused by a teacher for an ideal physical sciences lesson.

4. These categories at the same time give answer to the sub-problems of the research:

\subsection{Findings for Positive Features of a Teacher for an Ideal Physical Sciences Lesson}

Positive teacher features for an ideal Physical Sciences 
class according to 40 teacher candidates are summarized in Table 1. Most of the teacher candidates defined these features as positive attitudes and features of a teacher in an ideal class: Ensuring students become active and productive in a class, preparing rich learning environments, associating lessons with daily life, working for developing positive attitudes about physical sciences lesson.

Table 1. Positive teacher features for an ideal physical sciences lesson

\begin{tabular}{|c|c|}
\hline $\begin{array}{c}\text { Positive Teacher Features for an Ideal Physical } \\
\text { Sciences Lesson }\end{array}$ & Frequency \\
\hline Ensuring students become active participants & 32 \\
\hline Preparing rich learning environments & 26 \\
\hline Associating lessons with daily life & 24 \\
\hline $\begin{array}{c}\text { Working for developing positive attitudes about } \\
\text { physical sciences lesson }\end{array}$ & 22 \\
\hline Completing all preparations before lesson & 20 \\
\hline Revealing students' foreknowledge & 19 \\
\hline $\begin{array}{l}\text { Working for improving environmental } \\
\text { consciousness }\end{array}$ & 18 \\
\hline Making experiments in class frequently & 17 \\
\hline Working for improving creativity of students & 16 \\
\hline Guiding students & 16 \\
\hline Using materials frequently & 16 \\
\hline Using different methods and techniques & 16 \\
\hline $\begin{array}{l}\text { Working for improving students' problem solving } \\
\text { abilities }\end{array}$ & 15 \\
\hline $\begin{array}{c}\text { Taking developmental level of students into } \\
\text { consideration }\end{array}$ & 14 \\
\hline $\begin{array}{l}\text { Working for improving scientific thinking abilities } \\
\text { of students }\end{array}$ & 14 \\
\hline $\begin{array}{c}\text { Paying attention to student interests and } \\
\text { characteristics }\end{array}$ & 13 \\
\hline Following scientific developments & 12 \\
\hline
\end{tabular}

\begin{tabular}{|c|c|}
\hline $\begin{array}{c}\text { Making assessment and evaluation frequently through } \\
\text { different assessment methods }\end{array}$ & 12 \\
\hline Making detailed research about the target topics & 12 \\
\hline Ensuring discipline in class & 10 \\
\hline Paying attention to student security & 9 \\
\hline Developing the ability to imagine & 8 \\
\hline Giving importance to group studies & 8 \\
\hline Ensuring establishing association with other classes & 8 \\
\hline Being able to keep listening skills at a high level as a \\
teacher & 7 \\
\hline Including students in evaluation process & 7 \\
\hline Giving value to different thoughts and projects & 7 \\
\hline Discussing student homework and studies & 4 \\
\hline
\end{tabular}

Views of teacher candidates about positive teacher features for an ideal physical sciences class are as follows:

'Students' active participation is highly important. A teacher should be intolerant about inactive students in a class. Teacher can activate students through various activities in a class.” T1.
"Active learning should be supported by using in-class activities. Obtained information can be turned into meaningful acquisitions through active learning” T36.

"It is important to create proper learning environments for ensuring students realize their potential. Each student is special, this is why, there are various things to be used in a class to attract the attention of students" T27

"Physical sciences teacher should be environment friendly. Teacher should set an example for increasing awareness and protection of environment and he/she should demonstrate practices” T19.

"Experiments are very important for an ideal physical sciences class; they should be frequently involved in lessons. Experiment materials can be broken or worn out. Teacher should be aware of that and be flexible about it." T15.

"There should be various materials in a class while teaching a topic. Students should always be in interaction with materials. They will learn and acquire much easily through interaction” T34.

"We are at the age of science and technology. I believe that a qualified physical sciences teacher should follow science and technology. For instance, he/she should know new software programs that may attract the attention of students and use such programs in class” T40.

"I think that it is very important to be a teacher that guides students towards asking questions. I would give time to students for thinking and researching these questions” T6.

\subsection{Findings about Negative Teacher Features in Physical Sciences Lesson}

Ideas about negative teacher features in Physical Sciences class obtained from 40 teacher candidates are summarized and presented in Table 2. Teacher candidates stated that such negative teacher attitudes are: Making teacher-centered studies, disheartening students about learning, starting class without making any preparations and restricting questions or not allowing students ask questions at all.

Views of teacher candidates about negative teacher features in an ideal physical sciences class are as follows:

"I think that the general understanding about teaching is negative. I think that the process of teaching completely based on -teacher- is very boring and wrong. I believe that teacher-centered approach turns students into passive beings and I won't adopt such a teaching process in my class" T11

"Student willingness is very important. Unfortunately, some teachers don't give sufficient significant to this issue. When teachers make negative statements about students, they naturally use motivation and willingness" T23.

"Teacher should make some preparations before the class and should be able to use time efficiently. A teacher who doesn't carry out these should immediately leave the 
class” T28.

Table 2. Negative teacher features in physical sciences lesson

\begin{tabular}{|c|c|}
\hline $\begin{array}{c}\text { Negative Teacher Features in Physical Sciences } \\
\text { Lesson }\end{array}$ & Frequency \\
\hline Making teacher-centered studies & 30 \\
\hline Disheartening students about learning & 26 \\
\hline Starting class without making any preparations & 16 \\
\hline Restricting student questions & 15 \\
\hline Using similar methods and techniques all the time & 14 \\
\hline Making students worry about grades & 13 \\
\hline Always focusing on specific, same students & 12 \\
\hline Weak communication skills & 8 \\
\hline Making too much written or oral examinations & 8 \\
\hline Not taking safety precautions & 7 \\
\hline Going off the subject & 6 \\
\hline Giving too much homework & 6 \\
\hline Sticking to the computer & 5 \\
\hline Focusing on abstract issues while teaching & 4 \\
\hline
\end{tabular}

“Teachers shouldn't always use same tactics during classes. Methods and techniques should be improved and changed in order to attract the attention of students" T18.

"I don't think that computer or presentation based teaching method is proper. Concrete and direct practices are more appropriate for physical sciences class, complete dependence on computer should be avoided” T14.

\subsection{Findings about the Issues that should be Researched and Focused by a Teacher for an Ideal Physical Sciences Class}

Topics that should be researched, analyzed and focused for an ideal physical sciences class based on the data collected from 40 teacher candidates are summarized in Table 3. Most of the teacher candidates stated that: It is necessary to listen to the ideas of students about class, it is important to clearly explain the significance of physical sciences class; it is significant to research methods that would make lessons more enjoyable and to focus on associating theoretical information with daily life.

Views of teacher candidates about what teachers should research and prioritize for an ideal physical science class are as follows:

"It should always be remembered that students are special, unique. Their ideas and wishes about lessons are important. Right now we are still students. We take teachers who give importance to us as role models” Т33.

"It is important to focus on laboratory approaches and experiments. For instance, there are various experiments that can be done with eggs. Experiments can be done and improved for supporting the issues that are taught in science classes” T34.

"Association of a lesson with daily life is important.
Teachers should give examples and make researches for this purpose” $\mathrm{T} 2$.

"Teachers can easily practice physical sciences lessons out of classes. He/she can arrange tours outside the school; he/she can direct students for making experiments and observations out of the school environment. In my opinion, physical sciences teacher should take students out of classrooms and give them the opportunity to directly discover the nature” T20.

"Teachers should plan and make researches about materials that might be used in class while introducing a topic. Material use is necessary for physical sciences lessons; materials concretize the information given in lessons" T9.

Table 3. The issues that should be researched and focused by a teacher for an ideal physical sciences class

\begin{tabular}{|c|c|}
\hline $\begin{array}{c}\text { The Issues that should be Researched and Focused } \\
\text { by a Teacher for an Ideal Physical Sciences Class }\end{array}$ & Frequency \\
\hline $\begin{array}{c}\text { Listening to the ideas, suggestions and requests of } \\
\text { students about class }\end{array}$ & 23 \\
\hline $\begin{array}{c}\text { Experiments about the subject } \\
\text { association with daily life }\end{array}$ & 16 \\
\hline $\begin{array}{c}\text { Importance of the physical sciences topic and its } \\
\text { enjoyable }\end{array}$ & 16 \\
\hline Using materials in class & 15 \\
\hline Scientific process skills & 14 \\
\hline Methods and techniques that make classes active & 12 \\
\hline Topics that are difficult for students & 11 \\
\hline Out-of-school learning environments & 10 \\
\hline Safety of student & 9 \\
\hline Ensuring experiment variety and application skill & 9 \\
\hline Grading scales & 8 \\
\hline Teacher sufficiency special to the field of physical \\
sciences & 7 \\
\hline Making correction and giving feedback to students & 6 \\
\hline Supplementary source books & 5 \\
\hline Having the support of school management & 3 \\
\hline
\end{tabular}

\section{Result and Discussion}

Surely the ideas and efforts of classroom teachers who are together with the students in their very first few years are highly important for education. Thoughts, behaviors and efforts of classroom teachers about physical sciences classes should always be taken into consideration and thoroughly discussed in order to be able to establish proper and fruitful sciences education.

This study, focusing on presenting the views of primary school classroom teachers about physical sciences class, shows the features that every teacher should have and give information about some significant characteristics that should be adopted by teachers who are willing to create qualified learning environments for physical sciences 
education. Teacher candidates who are involved in this study generally mentioned and emphasized that it is necessary to support active participation of students, use materials, and take students' characteristics into consideration, use different methods and techniques. These ideas can also be applied to other classes. The research also presents teacher features that are more important for physical sciences lessons. Using laboratories frequently, giving effort to increase student creativity and to create scientific process skills, giving importance to imagination are some of these features.

This study reveals that teacher candidates in classroom education department who took physical sciences education lessons during university education have some important ideas about features that teachers should have; this fact implies that awareness level of these teacher candidates is high. Bulut Ozsezer and Iflazoglu Saban [10] conducted a study that involved teacher candidates in classroom education department and they determined that participants generally know what should be done and what should be avoided in order to create a positive atmosphere in classes. Anagün, Kılıç, Atalay and Yaşar [7] made a similar research and found that teacher candidates in classroom education department mostly stated that they are sufficient for practicing Physical Sciences Education Program.

In addition, it can be seen that the findings of these studies reveal many important concepts for an ideal science course. Although this study simply presents each viewpoint in the form of view frequency, researchers can focus on the views presented in this study separately and make more detailed analyses.

\section{REFERENCES}

[1] MEB. (2017). Fen bilimleri dersi öğretim programı (ilkokul ve ortaokul 3, 4, 5, 6, 7 ve 8 . siniflar). [Science curriculum teaching program (elementary school and middle school 3rd , 4th , 5th , 6th , 7t and 8th grades).] Ankara: Talim ve Terbiye Kurulu Başkanlığı.

[2] MEB. (2018). Fen bilimleri dersi öğretim programı (ilkokul ve ortaokul 3, 4, 5, 6, 7 ve 8 . siniflar). [Science curriculum teaching program (elementary school and middle school 3rd , 4th , 5th , 6th , 7t and 8th grades).] Ankara: Talim ve Terbiye Kurulu Başkanlığı.

[3] Arends, R. I. (2012). Learning to teach (9th Ed.). New York: TheMcGraw-HillCompanies, Inc.

[4] Martin, D. J. (1997). Elementary science methods: a constructivist approach. USA: Delmar Publishers, An International Thomson Publishing Company.

[5] Celep, C. (2004). Meslek olarak öğretmenlik. [Teaching as a profession] C. Celep (Ed.), Meslek olarak öğretmenlik [Teaching as a profession] (s. 23-49) içinde. Ankara: Anı Yayınc1lı.
[6] Akben, N. (2018). Sınıf öğretmeni adaylarının uygulamaya dayalı fen öğretime ilişsin görüşleri. [Classroom teacher candidates' views on practice-based science teaching.] Ankara University Faculty of Educational Sciences Journal, 51(3), 145-168. doi: 10.30964/auebfd.447336

[7] Anagün, Ş. S., Kılıç, Z., Atalay, N. \& Yaşar, S. (2015). Sınıf öğretmeni adayları fen bilimleri öğretim programını uygulamaya hazır mi? [Are class teacher candidates ready to apply the science curriculum?] Turkish Studies, 10(11), 127-148.

doi:http://dx.doi.org/10.7827/TurkishStudies.8611

[8] Arsal, Z. (2013). Fen öğretimi derslerinin yapılandırmacı öğrenme ortamı açısından değerlendirilmesi. [Evaluation of science teaching courses in terms of constructivist learning environment.] Elementary Online, 12(4), 1016-1031.

[9] Buldu, N., Buldu, M. \& Buldu, M. (2014). Türkiye'de anasınıflarında ve ilkokul 1, 2 ve 3. sınıflarda fen öğretimi üzerine bir kalite değerlendirmesi. [Kindergarten and primary schools in Turkey 1, a quality evaluation on the 2nd and 3rd grades in science education.] Education and Science, 39(174), 214-232. doi:http://dx.doi.org/10.15390/EB.2014.2974

[10] Bulut Ozsezer, M. S. \& Iflazoglu Saban, A. (2016). An investigation on teacher candidates' perspectivesaboutbehaviorspositivelyaffectingclassroomat mosphere. Eurasian Journal of Educational Research, 66, 139-158. http://dx.doi.org/10.14689/ejer.2016.66.8

[11] [11] Çray Özkara, F. \& Güven, M. (2018). Sınıf öğretmeni adaylarının fen eğitimine yönelik gereksinimlerinin belirlenmesi. [Determining the requirements of the prospective teachers for science education.] Journal of Qualitative Research in Education, 6(3), 158-184.

[12] Özden, M., Kara, A. \& Tekin, A. (2008). Öğretmen adaylarının fen bilgisi öğretimi dersine ilişkin tutumları. [Attitudes of prospective teachers towards science teaching lesson.] Electronic Journal of Social Sciences, 7(23), 352-377.

[13] Tuluk, G. (2015). Öğretmen adaylarının öğretmen öz-yeterlilikleri üzerine bir inceleme. [A study on teacher self-efficacy of teacher candidates.] Uşak University Journal of Educational Research, 1(1), 1-15.

[14] Yener, D. \& Yılmaz M. (2017). Öğretmen adaylarının öğrenme öğretme anlayışları ve fen öğretimine yönelik özyeterlik inançları. [Teachers' teaching conceptions of learning and self-efficacy beliefs about science teaching.] Journal of Education Faculty of Abant Izzet Baysal University, 17(2), 1016-1038.

[15] Yıldız Duban, N. \& Gökçakan, Y. (2013). Sınıf öğretmeni adaylarının fen öğretimi öz-yeterlik inançları ve fen ögretimine yönelik tutumları. [Classroom teacher candidates' self-efficacy beliefs and attitudes towards science teaching.] Cukurova University Journal of the Institute of Social Sciences, 21(1), 267-280.

[16] Yıldırım, A. \& Şimşek, H. (2013). Sosyal bilimlerde nitel araştırma yöntemleri. [Qualitative research methods in the social sciences.] Ankara: Seçkin Yayıncılık.

[17] Patton, M.Q. (2002). Qualitative research and evaluation methods (3rd Ed.). London: Sage Publications, Inc. 